TURIZAM

Volume 21, Issue 1

$1-18$ (2017)

ORIGINAL

SCIENTIFIC PAPER

\title{
Measuring the Efficiency of Tourism Sector and the Effect of Tourism Enablers on Different Types of Tourism (Kurdistan)
}

\author{
Fatih Cura ${ }^{A}$, Uma Shankar Singh ${ }^{A}$, Karwan Talaat ${ }^{A}$ \\ Received: October 2016 | Accepted: March 2017 \\ DOI: 10.18421/TRZ21.01-01
}

\begin{abstract}
The research problem observed that the most important need is to understand the different types of tourism available or can get established and what are the different factors called enablers are affecting different types of tourism. The study conducted is exploratory in nature and the inductive approach of research has been taken to frame a new concept with the sample size taken of 160. The geographic scope of this study is set in the Kurdistan region of Iraq with measuring the six enablers of tourism sector namely geographic, public infrastructure, social infrastructure, political stability, competitive environment and security with five types of tourism are health tourism, business tourism, education tourism, religion tourism, sports tourism. For the presentation of concept a conceptual model framed and further reframed based on the outcome offactor analysis. The Frequency, Percentage, Confirmatory Factor Analysis and Regression Analysis are conducted for statistical testing and data analysis. Research objectives formulated are to know how different types of tourism and tourism enablers are affecting the tourism sector, to measure the efficiency of different types of tourism and the status of tourism enablers, to measure the relationship and effectiveness of tourism enablers on tourism sector. The strength of relationship adjusted $R^{2}$ is 0.615 shows that there is a strong positive relationship in between independent variable (Tourism Enablers) on dependent variable (Types of Tourism). The value of beta is 0.786 can get interpreted as the independent variable (Tourism Enablers) has 0.786 or $78 \%$ effect on dependent variable (Types of Tourism). In the future the health and education tourism can also get established, condition to developing all dimensions of tourism enablers.
\end{abstract}

Key Words: Tourism Enabler, health tourism, business tourism, education tourism, religion tourism, sports tourism

A Faculty of Administrative Sciences and Economics, ISHIK University, Erbil, Kurdistan, umashankar.singh@ishik.edu.iq; faith.cura@ishik.edu.iq; karwan.talaat@ishik.edu.iq 


\section{Introduction}

Tourism sector is one of the highest contributors to the GDP of many economies. The main aim of this study is to get the better understanding of tourism sector as the business that can be a contributor for the development of economy as well the exposing of one economy to other economies. Some economies even are solely dependent on tourism sector. The study is focused at the development concern of tourism sector of Kurdistan. The geographic scope of this study is set in the Kurdistan region of Iraq with measuring the six enablers of tourism sector namely geographic, public infrastructure, social infrastructure, political stability, competitive environment and security with five types of tourism are health tourism, business tourism, education tourism, religion tourism, sports tourism. Though the Kurdistan has a strong ability to attract tourism then too, it is very important to review the status and suggest the concern of improvements of the sector. Domestic tourism is influenced rather by the provincial and national economy, and generally has lesser prerequisites as compared to foreign tourism. However, the profitability potential for domestic tourism is also considerably lower compared to foreign tourism. The nationals of a country are simply never going to be willing to spend a large volume of funds on artifacts and services with which they are already familiar. In stark contrast with foreign tourists who generally lack the means of knowing the actual cost a product or service, and purchase it as part of experiencing all of what the region or country has to offer (Severt, et al., 2007). On the converse side, if the global economy goes into depression, lesser people will have the financial resources to afford tourism. Moreover, for those who are still able to afford touring other countries will have minimal expenditure, therefore reducing their effectiveness towards the profitability of the tourism industry. Moreover, the fact that the global economy functions on cycles to positive and negative extent, this decline and recline could be considered a natural process therefore not requiring any specific remedy. However, the extent to which a decline can influence the Iraqi Kurdistan tourism industry has been considerably debated in the present literature. Furthermore, the greater challenge stemming from the global economy is the decay of established private structure during times of global depression. Though it is imperative that once the global economy goes into depression, the condition will reverse in the coming year (EKurd, 2015).

However, waiting for such considerable periods is usually not viable for the tourism industry of the Iraqi Kurdistan - particularly owing to the large volume of competing establishments. This makes it considerably harder for some institutions to continue operating profitably, leading to their eventual closure. Each closure can have a substantial influence on the Iraqi Kurdistan economy, as tourism constitutes a major source of revenue. Furthermore, the lost and withdrawn establishments are generally considerably difficult to replace in a sufficient timeframe, specifically when the global economy turns around and tourism can initiate once again (Ray, et al., 2006). The sole remedy is for Iraqi Kurdistan to facilitate measures to maximize the potential, revenue, and attractiveness of the tourism industry during times of positive global economy performance. This includes enhanced advertisements and contracts with various institutions around the world to direct more tourism towards Iraqi Kurdistan. The present context, the general condition of tourism sites in Iraqi Kurdistan is poorly maintained. In accordance with the literature review, a great extent of tourism sites are in a terrible condition, so worse that they are no longer capable of attracting tourism (Lim, Lee, 2006). There needs to be considerably greater effort from the governments in effect to maintain the sites. There are several possible remedies to this considerable challenge, as in the long term, the poor maintenance of tourism sites can lead to complete collapse of the conventional tourism sector. It remains important to note that this challenge is 
by far the simplest to overcome through legislative power and direction of financial resources (Tourism Board., 2015). The challenge is also imperative to overcome. The premier remedy is to launch reparation and maintenance scheme of generally depleted tourism sites. This is achieved through making damage assessments, and acquiring the material and financial resources necessary to repair the damages. Furthermore, the next important and long-term solution is to enact special garbage collection units that are supposed to collect all possible garbage from tourism areas throughout the year and specifically more so in the tourism season. Though maintenance, specifically cleaning, costs significant financial resources, the benefit obtained in the longer run are more than sufficient towards offsetting the costs (Oliveria, 2014).

\section{Literature Review}

In various countries and tourism types, there are specific period during which tourism activity will raise (Allen, 2002). A few destinations and types receive tourists consistently whilst most other destinations, including religious tourism types, are based on identified times. It has widely been recognized that the specific season can also have a substantial influence on tourism. Each type of tourism has its own necessary input and output, each with a unique set of challenges that needs to be overcome in order for the industry to develop and prosper as whole. Iraqi Kurdistan requires assessment for the various type of tourisms - however, it is undeniable that traveling tourism constitutes the primary product of Iraqi Kurdistan's tourism (Mehmetoglu, Ellingsen, 2005).

Health Tourism, particularly prominent in countries with advanced medical experiences and professions. These countries usually offer treatment of diseases that are not found elsewhere, or these countries may have institutions that offer inexpensive treatment of conditions and diseases that are substantially more expensive in other countries. Business tourism is another particular type of tourism (Ayob, 2014). This tourism opportunity is generated through having a sufficient business atmosphere, provided through both the social spectrum as well as government legislations. This type of tourism may also benefit the established tourism industry, for example, the conditions of the country may influence a world-renowned resort owner to launch their business in the country, further boosting the overall tourism potential. If there is a lack of business tourism, neither foreign investment nor any foreign technologies will be brought into the country, making it harder for economic or social development to occur. Domestic tourism is defined as tourists attending the various geographical or cultural hotspots of the country (Anwar, Sohail, 2004). This type of tourism is not provided sufficient emphasis, particularly due to its low financial potential and social impact. Iraqi Kurdistan is a country widely recognized for experiencing boons of foreign tourism entering the country in the previous decade, therefore providing its industry the notion that foreign influx will keep on raising in an infinite loop (Weber, Ladkin, 2004). However, the change of events wrecked the industry that was modeled to the demands of foreign tourism.

It needs to be assessed if whether there is any significant demand from domestic tourists. Moreover, the accommodations made by the tourism industry to accommodate domestic tourists also need assessment (Thett, 2012). The presence of world-renown educational institutions can also increase tourism rates, labeled as educational tourism where individuals arrive in order to acquire an education. Religious tourism constitutes tourism based on holy events or pilgrimages. These events occur annually, bi-annually or even multiple times per year (Tum, Wright, 2006). An excellent example for this is Hajj, a pilgrimage to Mecca performed by Muslims. Perhaps the second 
most popular incarnation of tourism, Sports tourism is one that observes visitors arriving in large numbers to watch a sports tournament or league, which in many cases last up to two months. Specific examples of these include FIFA World Cup, Cricket World Cup, Hockey World Cup etcetera. Sports tourism has a major role in the tourism industry (Van der, 2006).

A popular international sports event usually attracts hundreds of thousands of fans. Sports tourism is highly helpful to the country in economic terms. Any country that is hosting a popular world cup is often considered to be in a momentary golden age due to global coverage (Barker, Meyer, 2003). In order for a country to derive traveling tourism, it needs to ensure that there are sufficient geographical features that attract foreign visitors into the country (Sherwood, 2007). The failure to meet this fundamental objective will lead to no participation in the tourism industry. If no geographical sites exist, they need to be created through artificial means. This refers to the construction of interesting buildings and objects that will attract tourists through their uniqueness. An excellent representation for this would be the Eiffel tower located in Paris, France. Paris has no specific areas worthy of mention that attracts the same volume of interest, in contrast to the Eiffel tower. Tourists from all over the world enter Paris to observe the tower's magnificence. Niagara Falls is an excellent of a natural tourism attraction. Both sources can yield a tremendous amount of tourism, provided there is enough intrigue (Weed, 2005). Nevertheless, intrigue is highly subjective by nature. Iraqi Kurdistan hosts a wide assortment of geographical locations that have the potential to attract a large volume of foreign tourists. Such was already the case until the repercussions of ISIL's launch afflicted Kurdistan. The level of government and public infrastructure is another important enabler of an effective tourism industry (Brannas, Nordstrom, 2006).

Lacking proper infrastructure, there would be no means for tourisms to enter and enjoy a pleasant stay in the country. Aspects of public infrastructure includes sufficient road networks, airport networks, railway networks, sea networks, telecommunications, water availability, law enforcement and legislatures that protects and promotes tourists' rights. Social infrastructure is defined as the infrastructure that falls under the responsibility of society members (Waitt, 2004). This includes cultural values as well as personal entrepreneurships. In order to promote and accommodate tourism, the people of the society should be willing to accept foreigners and domestics alike, i.e. providing hospitality. People living in the society are primarily responsible for setting up sufficient industry that caters to foreigners entering the country, supported through the government; the industry established by the people is the defining capacity of the country's tourism (Hannam, Halewood, 2006). This includes touring agencies, who would offer traveling deals under competitive pricing to attract customers. Hotels are another example; there must be hotels of various ratings to accommodate all types of tourists arriving in the country. Having a stable government that is not at the risk of overthrow is the fundamental demand of enabling foreign tourism (Jago, Dwyer, 2006). Governments all around the world actively discourage its citizens to maintain any tourism or financial contracts under countries that are militarily or politically unstable. Any type of political instability can cause travel warnings to be issued to nationals from all foreign countries, even prompting their immediate departure from the country (Yoon, et al., 200o). This type of instability is similar in effect to regional instability and poor security; however its administration lies in the hands of the nation's citizen and its government. Thus, better administration can mitigate political instability, increasing the tourism viability of the country (Dwyer, et. al., 2005).

The primary motivator for the tourism industry - no matter the type is the amount of variety and options available (Hinch, et al., 2006). In an ideal tourism environment, there should be multiple services for the same kind of approach, e.g. there should be several types of hotel, 
in varying classification for luxury and budget. The specific cultural items should always be available under a competitive environment, e.g. in tourism hotspots, there should ideally be multiple sellers selling the same cultural objects, bought for their gifting and keepsake values. Not only does a competitive environment encourages an indirect increase in tourism rates, but also positively boosts the tourism industry participating from the labor force, e.g. new businesses, freelance merchants, restaurants, cafes (Yahoo News., 2015). Alongside boosting the tourism industry, these institutions also boost the national economy. Likewise, competitiveness should also be in tourism packages, a favored approach of international tourists who are unfamiliar with the geography and cultural factors of the country (Chalip, Costa, 2006). If a wide array of tour operators provides an equally wide array of unique travelling destinations and resorts under their programs, it can increase tourism output. A lack of competitive environment is a major cause of challenge to the development of tourism industry. If no variety is present in an industry that sells itself on the title of variety, the performance of the said industry will be depressing. The security situation of a country is an important factor when Tourism is concerned (Xiao, Smith, 2004). Security refers to the presence of enough law enforcement and rescue organizations operating within the country. Though it is highly unlikely that a country may not any functional law enforcement at all, the effectiveness of its implementation varies. In order to promote Tourism, the tourist must be made to feel safe roaming around the country with the guarantee that there are neither terrorists nor bandits roaming (Gammon, Kurtzman, 2002). Furthermore, there also needs to be appropriate response to emergencies such as firefighting service and ambulances (Donovan, Debres, 2006).

\section{Research Problem}

The tourism functioning of Kurdistan, which has been significant since the previous decade, has been dependent heavily on the state of the global economy (Tuli, 2014). It is the same as any of the world economy or any tourism industry that depends on foreign tourists. People visiting Iraqi Kurdistan, specifically those working on payrolls are greatly influenced by how the global economy performs (Ahmad, 2014). Any positive increase in the global economy may generally translate onto increased tourism output for various tourism industries throughout the world. The positive conditions means that prospective individuals may be more willing to enter into the country for tourism, alongside being able to spend more on the various facilities and amenities; hotels, restaurants, tourist packages and tourism sites. The extensive literature review lead to the understanding the research problem that, the most important need is to understand the different types of tourism available or can get established and what are the different factors called enablers are affecting different types of tourism.

\section{Research Objectives}

For the better understanding of the tourism sector with different types of tourism and its enablers, and moreover to find the solution for the research problem observed following objectives formulate are: (1) To know how different types of tourism and tourism enablers are affecting the tourism sector (2) To measure the efficiency of different types of tourism and the status of tourism enablers (3) To measure the relationship and effectiveness of tourism enablers on tourism sector. 


\section{Research Methodology}

The study is exploratory in nature where based on the literature review many variables collected and incorporated. The inductive approach of research has been taken to frame a new concept and has got testes using statistical tests. The geographic scope of the study is Kurdistan region of Iraq. The simple random sampling method of probability sampling has been chosen to study 160 samples. For the sample size selection (Cohen, 1992) selected considering the regression statistical test. In the beginning, it got 200 samples for the data collection by different ways like personal visit to respondents in ministry, online questionnaire preparation and sends it to mass respondents participating in social activities, so the response rate is $80 \%$. For the presentation of concept a conceptual model framed and further reframed based on the outcome of factor analysis. The Frequency, Percentage, Confirmatory Factor Analysis and Regression Analysis are conducted for statistical testing and data analysis.

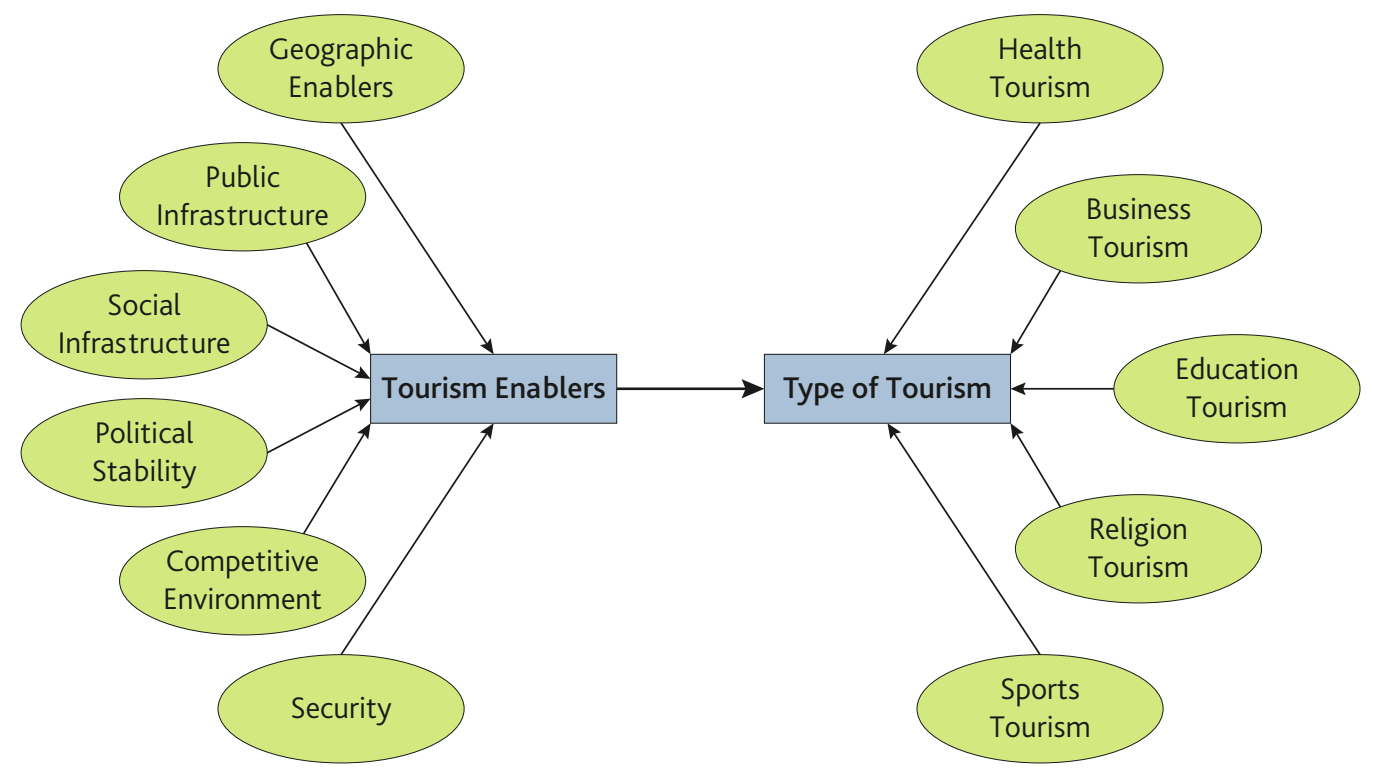

Figure 1. Conceptual Model

\section{Data Analysis}

The complete study is based on eleven variables where six are the independent and five are the dependent variable. The table shown below as "Reliability Statistics" Table 1 contains the explanation of all twenty two items forming eleven variables. All variables with all items are "Independent Variables (Tourism Enablers): Geographic Enablers measured as Natural beauty attract tourists, Historical buildings and monuments attract tourists, Public Infrastructure measured as Govt. has tourism development department, Govt. provides facilities for accommodation and tour for tourists, Social Infrastructure measured as Cultural values are open for tourists, Treats foreign tourists as the domestic population, Political Stability measured as Trust with the govt. is encouraging tourism, Financial planning and pricing are suitable for tourists, Competitive Environment measured as Different types of hotels are available for tourists; Cultural products 
are available for tourists to keep as memory, Security measured as Security measures are implemented for tourists, Law is enforced for the security measures" and "Dependent Variables (Types of Tourism): Health Tourism measured as Healthcare specialty attract tourists, Medical treatment is better and cheaper than neighboring countries, Business Tourism measured as Business opportunities attract tourists; Business investor gets support from govt. and people, Education Tourism measured as Educational institutions are the interest for foreign students; Ministry of Higher Education promotes the education facility for foreigners, Religion Tourism measured as Visit to religious places are the interest of foreigners, Religious memories attracts tourists to visit, Sports Tourism: Sports activities attract foreigners, Entertainment sports facilitate tourists". Here in this paragraph Govt. is considered "the representative of mass population elected by democratic process to work in offices having authority particular in ministry".

Table 1. Reliability Statistics

\begin{tabular}{|c|c|}
\hline Cronbach's Alpha & N of Items \\
\hline .941 & 22 \\
\hline
\end{tabular}

The Cronbach's Alpha value is .941 shows the instrument getting used is highly reliable in this study.

Table 2. Demographic Variables Description

\begin{tabular}{|c|c|c|c|}
\hline \multicolumn{2}{|l|}{ Parameter } & \multirow{2}{*}{$\begin{array}{c}\text { Frequency } \\
101\end{array}$} & \multirow{2}{*}{$\begin{array}{c}\text { Percentage } \\
63.1\end{array}$} \\
\hline Conder & Male & & \\
\hline Derive? & Female & 59 & 36.9 \\
\hline \multirow{5}{*}{ Age } & 16 Years-25 Years & 84 & 52.5 \\
\hline & 26 Years-35 Years & 55 & 34.4 \\
\hline & 36 Years- 45 Years & 14 & 8.8 \\
\hline & 46 Years-55 Years & 4 & 2.5 \\
\hline & 56 Years-above & 3 & 1.9 \\
\hline \multirow{2}{*}{ Marital Status } & Single & 105 & 65.6 \\
\hline & Married & 55 & 34.4 \\
\hline \multirow{5}{*}{ Education } & Secondary & 6 & 3.8 \\
\hline & Intermediate & 24 & 15.0 \\
\hline & Graduate & 92 & 57.5 \\
\hline & Post Graduate & 35 & 21.9 \\
\hline & Ph.D & 3 & 1.9 \\
\hline \multirow{5}{*}{ Family Income/ Month } & Up to $\$ 1000$ & 63 & 39.4 \\
\hline & $\$ 1001-\$ 2000$ & 35 & 21.9 \\
\hline & $\$ 2001-\$ 3000$ & 22 & 13.8 \\
\hline & $\$ 3001-\$ 4000$ & 13 & 8.1 \\
\hline & $\$ 4001$ and more & 27 & 16.9 \\
\hline \multirow{5}{*}{ Profession } & Student & 44 & 27.5 \\
\hline & Private Employee & 54 & 33.8 \\
\hline & Govt. Employee & 8 & 5.0 \\
\hline & Business & 45 & 28.1 \\
\hline & Self Employed & 9 & 5.6 \\
\hline \multicolumn{2}{|l|}{ Total } & 160 & 100 \\
\hline
\end{tabular}


Demographic variables are taken in the study are six in number as Gender, Age, Marital Status, Education, Family Income/ Month, Profession. The frequency and percentage outcome of demographical variables are presented as Table 2. All six variables are having different categories of responses and have got responses for all the categories differently, so the study has incorporated all the categories mentioned in the questionnaire to collect data. The first demographic variable is gender having two categories namely male and female having contribution $63.1 \%$ and $36.9 \%$ respectively. The female candidates are not as exposed to participation is such surveys in Kurdistan region. The Second demographic variable is age having five categories is 16 Years-25 Years, 26 Years-35 Years, 36 Years-45 Years, 46 Years-55 Years, 56 Years-above. As result of frequency in age the highest responses is age between 16 Years-25 Years having the highest $52.5 \%$, shows the youth participation is highest in this study. The third demographic variable is marital status having two categories namely single and married having contribution $65.6 \%$ and $34.4 \%$ respectively. Regarding the result the single candidates are more interested to responses for this survey and looking for tourism region. The Fourth demographic variables is education having 5 categories are Secondary, Intermediate, Graduate, Post graduate and $\mathrm{Ph} . \mathrm{D}$. depend on the frequently result identify most of the responses are in graduate level by $57.5 \%$ which means in Kurdistan region more than half of the respondents are between age 16 years to 25 years are graduated. The Fifth demographic variables is Family Income/ Month having 5categories are Up to \$1000, \$ $1001-\$ 2000, \$ 2001-\$ 3000, \$ 3001-\$ 4000$ and \$4001 and more. The highest family income per month among the responses is up to $\$ 1000$ is $39.4 \%$. Because growing up in Kurdistan Region of Iraq, a region which has faced continued turbulence, armed conflicts and financial crisis has had impact on the region. The Sixth demographic variables are Profession having five categories is students, Private Employee, Govt. Employee, Business and Self Employed. Those responses are working in private companies $33.8 \%$ and the lowest percent $5.0 \%$ who is working in the government means many of the responses or the residency are working in the private sector.

Items Description variables are taken in the study and presented as Table 3 are twenty two in number. All twenty two variables are having same five categories of responses and have got responses for all the categories differently, so the study has incorporated all the categories mentioned in the questionnaire to collect data. All Items are having five categories namely Strongly Disagree, Disagree, Neutral, Agree, Strongly Agree.

Table 3. Items Description

\begin{tabular}{|l|l|c|c|}
\hline \multicolumn{2}{|l|}{ Parameter } & Frequency & Percentage \\
\hline \multirow{4}{*}{$\begin{array}{l}\text { Natural beauty attract } \\
\text { tourists }\end{array}$} & Strongly Disagree & 7 & 4.4 \\
\cline { 2 - 4 } & Disagree & 4 & 2.5 \\
\cline { 2 - 4 } & Neutral & 51 & 31.9 \\
\cline { 2 - 4 } & Agree & 48 & 30.0 \\
\cline { 2 - 4 } & Strongly Agree & 50 & 31.3 \\
\hline \multirow{4}{*}{$\begin{array}{l}\text { Historical buildings and } \\
\text { monuments attract } \\
\text { tourists }\end{array}$} & Strongly Disagree & 8 & 5.0 \\
\cline { 2 - 4 } & Disagree & 10 & 6.3 \\
\cline { 2 - 4 } & Neutral & 29 & 18.1 \\
\cline { 2 - 4 } & Agree & 53 & 33.1 \\
\cline { 2 - 4 } & Strongly Agree & 60 & 37.5 \\
\hline
\end{tabular}




\begin{tabular}{|c|c|c|c|}
\hline \multicolumn{2}{|l|}{ Parameter } & \multirow{2}{*}{$\frac{\text { Frequency }}{14}$} & \multirow{2}{*}{$\frac{\text { Percentage }}{8.8}$} \\
\hline \multirow{5}{*}{$\begin{array}{l}\text { Govt. has tourism } \\
\text { development department }\end{array}$} & Strongly Disagree & & \\
\hline & Disagree & 14 & 8.8 \\
\hline & Neutral & 69 & 43.1 \\
\hline & Agree & 44 & 27.5 \\
\hline & Strongly Agree & 19 & 11.9 \\
\hline \multirow{5}{*}{$\begin{array}{l}\text { Govt. provides facilities for } \\
\text { accommodation and tour } \\
\text { for tourists }\end{array}$} & Strongly Disagree & 11 & 6.9 \\
\hline & Disagree & 19 & 11.9 \\
\hline & Neutral & 51 & 31.9 \\
\hline & Agree & 61 & 38.1 \\
\hline & Strongly Agree & 18 & 11.3 \\
\hline \multirow{5}{*}{$\begin{array}{l}\text { Cultural values are open } \\
\text { for tourists }\end{array}$} & Strongly Disagree & 12 & 7.5 \\
\hline & Disagree & 9 & 5.6 \\
\hline & Neutral & 43 & 26.9 \\
\hline & Agree & 74 & 46.3 \\
\hline & Strongly Agree & 22 & 13.8 \\
\hline \multirow{5}{*}{$\begin{array}{l}\text { Treats foreign tourists as } \\
\text { the domestic population }\end{array}$} & Strongly Disagree & 16 & 10.0 \\
\hline & Disagree & 17 & 10.6 \\
\hline & Neutral & 52 & 32.5 \\
\hline & Agree & 50 & 31.3 \\
\hline & Strongly Agree & 25 & 15.6 \\
\hline \multirow{5}{*}{$\begin{array}{l}\text { Trust with the govt. is } \\
\text { encouraging tourism }\end{array}$} & Strongly Disagree & 9 & 5.6 \\
\hline & Disagree & 18 & 11.3 \\
\hline & Neutral & 54 & 33.8 \\
\hline & Agree & 56 & 35.0 \\
\hline & Strongly Agree & 23 & 14.4 \\
\hline \multirow{5}{*}{$\begin{array}{l}\text { Financial planning and } \\
\text { pricing are suitable for } \\
\text { tourists }\end{array}$} & Strongly Disagree & 11 & 6.9 \\
\hline & Disagree & 19 & 11.9 \\
\hline & Neutral & 46 & 28.8 \\
\hline & Agree & 55 & 34.4 \\
\hline & Strongly Agree & 29 & 18.1 \\
\hline \multirow{5}{*}{$\begin{array}{l}\text { Different types of hotels } \\
\text { are available for tourists }\end{array}$} & Strongly Disagree & 11 & 6.9 \\
\hline & Disagree & 9 & 5.6 \\
\hline & Neutral & 33 & 20.6 \\
\hline & Agree & 45 & 28.1 \\
\hline & Strongly Agree & 62 & 38.8 \\
\hline \multirow{5}{*}{$\begin{array}{l}\text { Cultural products are } \\
\text { available for tourists to } \\
\text { keep as memory }\end{array}$} & Strongly Disagree & 11 & 6.9 \\
\hline & Disagree & 14 & 8.8 \\
\hline & Neutral & 38 & 23.8 \\
\hline & Agree & 52 & 32.5 \\
\hline & Strongly Agree & 45 & 28.1 \\
\hline
\end{tabular}




\begin{tabular}{|c|c|c|c|}
\hline \multicolumn{2}{|l|}{ Parameter } & \multirow{2}{*}{$\frac{\text { Frequency }}{2}$} & \multirow{2}{*}{$\begin{array}{c}\text { Percentage } \\
1.3\end{array}$} \\
\hline \multirow{5}{*}{$\begin{array}{l}\text { Security measures are } \\
\text { implemented for tourists }\end{array}$} & Strongly Disagree & & \\
\hline & Disagree & 13 & 8.1 \\
\hline & Neutral & 42 & 26.3 \\
\hline & Agree & 45 & 28.1 \\
\hline & Strongly Agree & 58 & 36.3 \\
\hline \multirow{5}{*}{$\begin{array}{l}\text { Law is enforced for the } \\
\text { security measures }\end{array}$} & Strongly Disagree & 11 & 6.9 \\
\hline & Disagree & 12 & 7.5 \\
\hline & Neutral & 37 & 23.1 \\
\hline & Agree & 60 & 37.5 \\
\hline & Strongly Agree & 40 & 25.0 \\
\hline \multirow{5}{*}{$\begin{array}{l}\text { Healthcare specialty } \\
\text { attract tourists }\end{array}$} & Strongly Disagree & 10 & 6.3 \\
\hline & Disagree & 10 & 6.3 \\
\hline & Neutral & 43 & 26.9 \\
\hline & Agree & 45 & 28.1 \\
\hline & Strongly Agree & 52 & 32.5 \\
\hline \multirow{5}{*}{$\begin{array}{l}\text { Medical treatment is } \\
\text { better and cheaper than } \\
\text { neighboring countries }\end{array}$} & Strongly Disagree & 15 & 9.4 \\
\hline & Disagree & 20 & 12.5 \\
\hline & Neutral & 42 & 26.3 \\
\hline & Agree & 49 & 30.6 \\
\hline & Strongly Agree & 34 & 21.3 \\
\hline \multirow{5}{*}{$\begin{array}{l}\text { Business opportunities } \\
\text { attract tourists }\end{array}$} & Strongly Disagree & 1 & 6 \\
\hline & Disagree & 15 & 9.4 \\
\hline & Neutral & 36 & 22.5 \\
\hline & Agree & 70 & 43.8 \\
\hline & Strongly Agree & 38 & 23.8 \\
\hline \multirow{5}{*}{$\begin{array}{l}\text { Business investor gets } \\
\text { support from govt. and } \\
\text { people }\end{array}$} & Strongly Disagree & 4 & 2.5 \\
\hline & Disagree & 13 & 8.1 \\
\hline & Neutral & 42 & 26.3 \\
\hline & Agree & 51 & 31.9 \\
\hline & Strongly Agree & 50 & 31.3 \\
\hline \multirow{5}{*}{$\begin{array}{l}\text { Educational institutions } \\
\text { are the interest for foreign } \\
\text { students }\end{array}$} & Strongly Disagree & 16 & 10.0 \\
\hline & Disagree & 18 & 11.3 \\
\hline & Neutral & 49 & 30.6 \\
\hline & Agree & 49 & 30.6 \\
\hline & Strongly Agree & 28 & 17.5 \\
\hline \multirow{5}{*}{$\begin{array}{l}\text { Ministry of Higher } \\
\text { Education promotes the } \\
\text { education facility for } \\
\text { foreigners }\end{array}$} & Strongly Disagree & 11 & 6.9 \\
\hline & Disagree & 33 & 20.6 \\
\hline & Neutral & 33 & 20.6 \\
\hline & Agree & 62 & 38.8 \\
\hline & Strongly Agree & 21 & 13.1 \\
\hline
\end{tabular}




\begin{tabular}{|c|c|c|c|}
\hline \multicolumn{2}{|l|}{ Parameter } & \multirow{2}{*}{$\frac{\text { Frequency }}{8}$} & \multirow{2}{*}{$\frac{\text { Percentage }}{5.0}$} \\
\hline \multirow{5}{*}{$\begin{array}{l}\text { Visit to religious places are } \\
\text { the interest of foreigners }\end{array}$} & Strongly Disagree & & \\
\hline & Disagree & 16 & 10.0 \\
\hline & Neutral & 36 & 22.5 \\
\hline & Agree & 71 & 44.4 \\
\hline & Strongly Agree & 29 & 18.1 \\
\hline \multirow{5}{*}{$\begin{array}{l}\text { Religious memories } \\
\text { attracts tourists to visit }\end{array}$} & Strongly Disagree & 11 & 6.9 \\
\hline & Disagree & 15 & 9.4 \\
\hline & Neutral & 46 & 28.8 \\
\hline & Agree & 63 & 39.4 \\
\hline & Strongly Agree & 25 & 15.6 \\
\hline \multirow{5}{*}{$\begin{array}{l}\text { Sports activities attract } \\
\text { foreigners }\end{array}$} & Strongly Disagree & 9 & 5.6 \\
\hline & Disagree & 13 & 8.1 \\
\hline & Neutral & 42 & 26.3 \\
\hline & Agree & 61 & 38.1 \\
\hline & Strongly Agree & 35 & 21.9 \\
\hline \multirow{5}{*}{$\begin{array}{l}\text { Entertainment sports } \\
\text { facilitate tourists }\end{array}$} & Strongly Disagree & 16 & 10.0 \\
\hline & Disagree & 6 & 3.8 \\
\hline & Neutral & 58 & 36.3 \\
\hline & Agree & 35 & 21.9 \\
\hline & Strongly Agree & 45 & 28.1 \\
\hline \multicolumn{2}{|l|}{ Total } & 160 & 100 \\
\hline
\end{tabular}

All twenty two items and their highest representative categories are represented respectively as natural beauty attract tourists, strongly agree $31.3 \%$, Historical buildings and monuments attract tourists, strongly agree $37.5 \%$, Govt. has tourism development, neutral $43.1 \%$, Govt. provides facilities for accommodation and tour for tourists, agree 38.1\%, Cultural values are open for tourists, agree $46.3 \%$, Treats foreign tourists as the domestic population, neutral $32.5 \%$, Trust with the govt. is encouraging tourism, agree $35.0 \%$, Financial planning and pricing are suitable for tourists, Agree 34.4\%, Different types of hotels are available for tourists, strongly agree $38.8 \%$, Cultural products are available for tourists to keep as memory, agree $32.5 \%$, Security measures are implemented for tourists, strongly agree $36.3 \%$, Law is enforced for the security measures, agree $37.5 \%$, Healthcare specialty attract tourists, strongly agree $32.5 \%$, Medical treatment is better and cheaper than neighboring countries, agree $30.6 \%$, Business opportunities attract tourists, agree $43.8 \%$, Business investor gets support from govt. and people, agree $31.9 \%$, Educational institutions are the interest for foreign students agree $30.6 \%$, Ministry of Higher Education promotes the education facility for foreigners, agree $38.8 \%$, Visit to religious places are the interest of foreigners, agree $44.4 \%$, Religious memories attract tourists to visit, agree $39.4 \%$, Sports activities attract foreigners, agree $38.1 \%$, Entertainment sports facilitate tourists, neutral $36.3 \%$.

The confirmatory factor analysis carried on 22 items to get the eleven factors as explored by the concept. Out of twenty two items four items got discarded having isolated and very low factor loading. The two variables social infrastructure and political stability merged with all four items and competitive environment got merged with security having again four items all together. After confirming the seven factors the factor loading explained as for first factor 
Geographic Enablers for two items as 0.624 and 0.568 , the second factor Public Infrastructure having two items with factor loadings as 1.021, 0.796, the third factor Socio Political Environment named after social infrastructure and political stability merged with all four items having factor loading $0.292,0.367,0.621$ and 0.600 , the fourth factor Competitive Environment \& Security as well the same competitive environment got merged with security having again four items with factor loading as $0.605,0.397,0.396,0.373$, the fifth factor Business Tourism having two items with factor loading 0.826 and 0.588 , The sixth factor having two items with factor loading 0.586 and 0.617 , the seventh or last factor sports tourism has two items with factor loading 0.559 and 0.727 as shown in Table 4.

Table 4. Confirmatory Factor Analysis based on Components

\begin{tabular}{|c|c|c|c|c|c|c|c|c|}
\hline Variables & Dimension / Item No. & 1 & 2 & 3 & 4 & 5 & 6 & 7 \\
\hline \multirow{2}{*}{$\begin{array}{l}\text { Geographic } \\
\text { Enablers }\end{array}$} & Natural beauty attract tourists & 0.624 & & & & & & \\
\hline & $\begin{array}{l}\text { Historical buildings and monuments } \\
\text { attract tourists }\end{array}$ & 0.568 & & & & & & \\
\hline \multirow{2}{*}{$\begin{array}{l}\text { Public } \\
\text { Infrastructure }\end{array}$} & $\begin{array}{l}\text { Govt. has tourism development } \\
\text { department }\end{array}$ & & 1.021 & & & & & \\
\hline & $\begin{array}{l}\text { Govt. provides facilities for } \\
\text { accommodation and tour for tourists }\end{array}$ & & 0.796 & & & & & \\
\hline \multirow{4}{*}{$\begin{array}{l}\text { Socio Political } \\
\text { Environment }\end{array}$} & Cultural values are open for tourists & & & 0.292 & & & & \\
\hline & $\begin{array}{l}\text { Treats foreign tourists as the domestic } \\
\text { population }\end{array}$ & & & 0.367 & & & & \\
\hline & Trust with the govt. is encouraging tourism & & & 0.621 & & & & \\
\hline & $\begin{array}{l}\text { Financial planning and pricing are suitable } \\
\text { for tourists }\end{array}$ & & & 0.600 & & & & \\
\hline \multirow{4}{*}{$\begin{array}{l}\text { Competitive } \\
\text { Environment \& } \\
\text { Security }\end{array}$} & $\begin{array}{l}\text { Different types of hotels are available for } \\
\text { tourists }\end{array}$ & & & & 0.605 & & & \\
\hline & $\begin{array}{l}\text { Cultural products are available for tourists } \\
\text { to keep as memory }\end{array}$ & & & & 0.397 & & & \\
\hline & $\begin{array}{l}\text { Security measures are implemented for } \\
\text { tourists }\end{array}$ & & & & 0.396 & & & \\
\hline & Law is enforced for the security measures & & & & 0.373 & & & \\
\hline \multirow[b]{2}{*}{ Business Tourism } & Business opportunities attract tourists & & & & & 0.826 & & \\
\hline & $\begin{array}{l}\text { Business investor gets support from govt. } \\
\text { and people }\end{array}$ & & & & & 0.588 & & \\
\hline \multirow{2}{*}{ Religion Tourism } & $\begin{array}{l}\text { Visit to religious places are the interest of } \\
\text { foreigners }\end{array}$ & & & & & & 0.586 & \\
\hline & $\begin{array}{l}\text { Religious memories attracts tourists to } \\
\text { visit }\end{array}$ & & & & & & 0.617 & \\
\hline \multirow{2}{*}{ Sports Tourism } & Sports activities attract foreigners & & & & & & & 0.559 \\
\hline & Entertainment sports facilitate tourists & & & & & & & 0.727 \\
\hline
\end{tabular}

Table 5. Regression Model Summary

\begin{tabular}{|c|c|c|c|c|}
\hline Model & $\mathrm{R}$ & $\mathrm{R}$ Square & Adjusted R Square & Std. Error of the Estimate \\
\hline 1 & $.786^{\mathrm{a}}$ & .618 & .615 & .62008381 \\
\hline \multicolumn{4}{|r}{} \\
\hline
\end{tabular}


Table 6. Regression Coefficients

\begin{tabular}{|c|c|c|c|c|c|c|}
\hline \multirow{2}{*}{\multicolumn{2}{|c|}{ Model }} & \multicolumn{2}{|c|}{ Unstandardized Coefficients } & \multirow{3}{*}{$\begin{array}{c}\text { Standardized Coefficients } \\
\text { Beta }\end{array}$} & \multirow{3}{*}{$\begin{array}{c}\mathrm{t} \\
.000\end{array}$} & \multirow{3}{*}{$\begin{array}{r}\text { Sig. } \\
1.000 \\
\end{array}$} \\
\hline & & \multirow{2}{*}{$\frac{\text { B }}{2.901 \mathrm{E}-017}$} & \multirow{2}{*}{$\begin{array}{c}\text { Std. Error } \\
.049\end{array}$} & & & \\
\hline 1 & (Constant) & & & & & \\
\hline & Tourism Enablers & .786 & .049 & .786 & 15.985 & .000 \\
\hline & & & dent Variab & ypes of Tourism & & \\
\hline
\end{tabular}

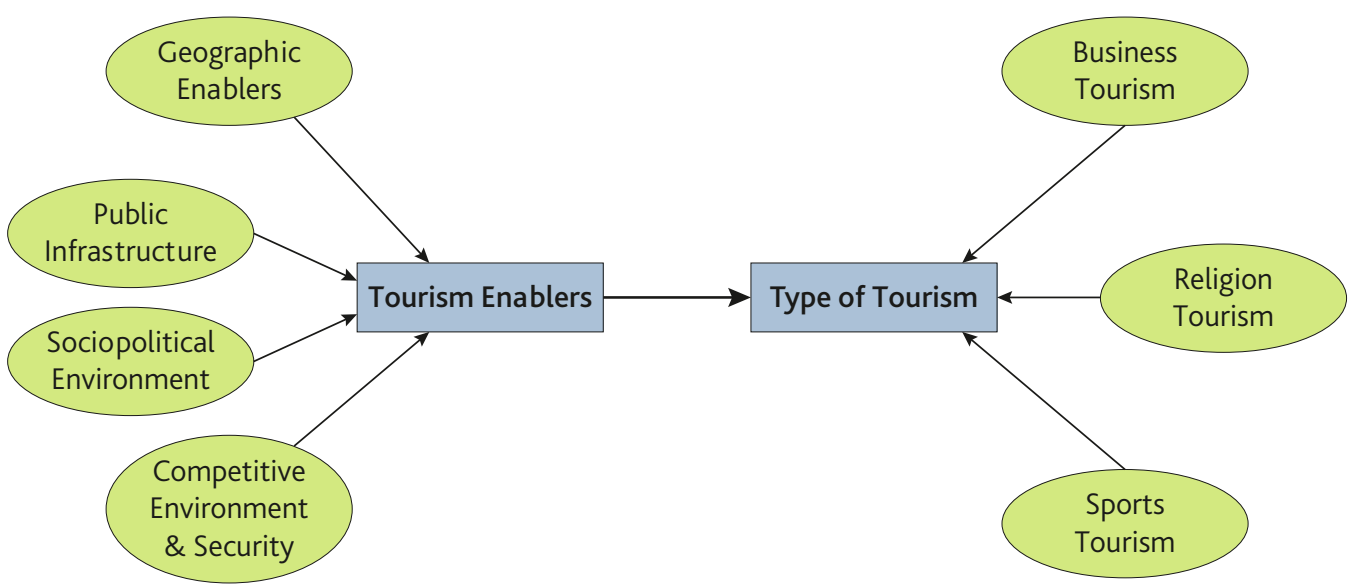

Figure 2. Conceptual Model based on Factor Analysis

The Table 5 is the outcome of regression model summary explaining the strength of relationship of independent variable (Tourism Enablers) on dependent variable (Types of Tourism). The strength of relationship adjusted $R^{2}$ is 0.615 shows that there is a strong positive relationship in between independent variable (Tourism Enablers) on dependent variable (Types of Tourism). The Table 6 is the representative of Beta value that represents outcome of regression coefficients explaining the effect of independent variable (Tourism Enablers) on dependent variable (Types of Tourism). The value of beta is 0.786 can get interpreted as the independent variable (Tourism Enablers) has 0.786 or $78 \%$ effect on dependent variable (Types of Tourism).

Table 7. CMIN

\begin{tabular}{|l|c|c|c|c|c|}
\hline Model & NPAR & CMIN & DF & P & CMIN/DF \\
\hline Default model & 57 & 382.617 & 114 & .000 & 3.356 \\
\hline Saturated model & 171 & .000 & 0 & & \\
\hline Independence model & 18 & 1776.966 & 153 & .000 & 11.614 \\
\hline
\end{tabular}

Table 8. RMR, GFI

\begin{tabular}{|l|c|c|c|c|}
\hline Model & RMR & GFI & AGFI & PGFI \\
\hline Default model & .086 & .802 & .703 & .535 \\
\hline Saturated model & .000 & 1.000 & & \\
\hline Independence model & .473 & .254 & .166 & .227 \\
\hline
\end{tabular}


Table 9. Baseline Comparisons

\begin{tabular}{|l|c|c|c|c|c|}
\hline Model & $\begin{array}{c}\text { NFI } \\
\text { Delta1 }\end{array}$ & $\begin{array}{c}\text { RFI } \\
\text { rho1 }\end{array}$ & $\begin{array}{c}\text { IFI } \\
\text { Delta2 }\end{array}$ & $\begin{array}{c}\text { TLI } \\
\text { rho2 }\end{array}$ & CFI \\
\hline Default model & .785 & .711 & .838 & .778 & .835 \\
\hline Saturated model & 1.000 & & 1.000 & & 1.000 \\
\hline Independence model & .000 & .000 & .000 & .000 & .000 \\
\hline
\end{tabular}

Table 10. RMSEA

\begin{tabular}{|c|c|c|c|c|}
\hline Model & RMSEA & LO 90 & HI 90 & PCLOSE \\
\hline Default model & .122 & .108 & .135 & .000 \\
\hline Independence model & .258 & .248 & .269 & .000 \\
\hline
\end{tabular}

The Table 7, Table 8, Table 9 and Table 10 are representing the CMIN, RMR, GFI, Baseline Comparisons and RMSEA respectively where all values presented in tables are supporting to fit the model for acceptance. All values are significant and showing more than 0.5 means, being in the accepted zone.

\section{Findings and Interpretation}

The study conducted here is based on the concept of cause effect relationship, where the Tourism Enablers are the causes and Tourism sector is effect. The data analysis has explained all the frequency and percentage of sample taken for the study with responses on all twenty two items. The research problem observed for the study has found its solution by the confirmatory factor analysis and revealed that respondents consider social infrastructure and political stability is very closer in this specific study of Kurdistan region, so all four items as the two different variables reframed as a new single variable named as Socio Political Environment. The same happened with the two variables again competitive environment and security clubbed in one as Competitive Environment \& Security having four items all together. As per the respondents opinion two types of tourism are health tourism and Education tourism get discarded. As it shows the Kurdistan region is not ready for these two types of tourism. The findings of the regression analysis are positive that says improvement in tourism enablers can make the tourism sector sustainable and can attract tourists. The values generated by the outcome of AMOS model also support the concepts with very high values. These high values are further supporting the existing concept. 


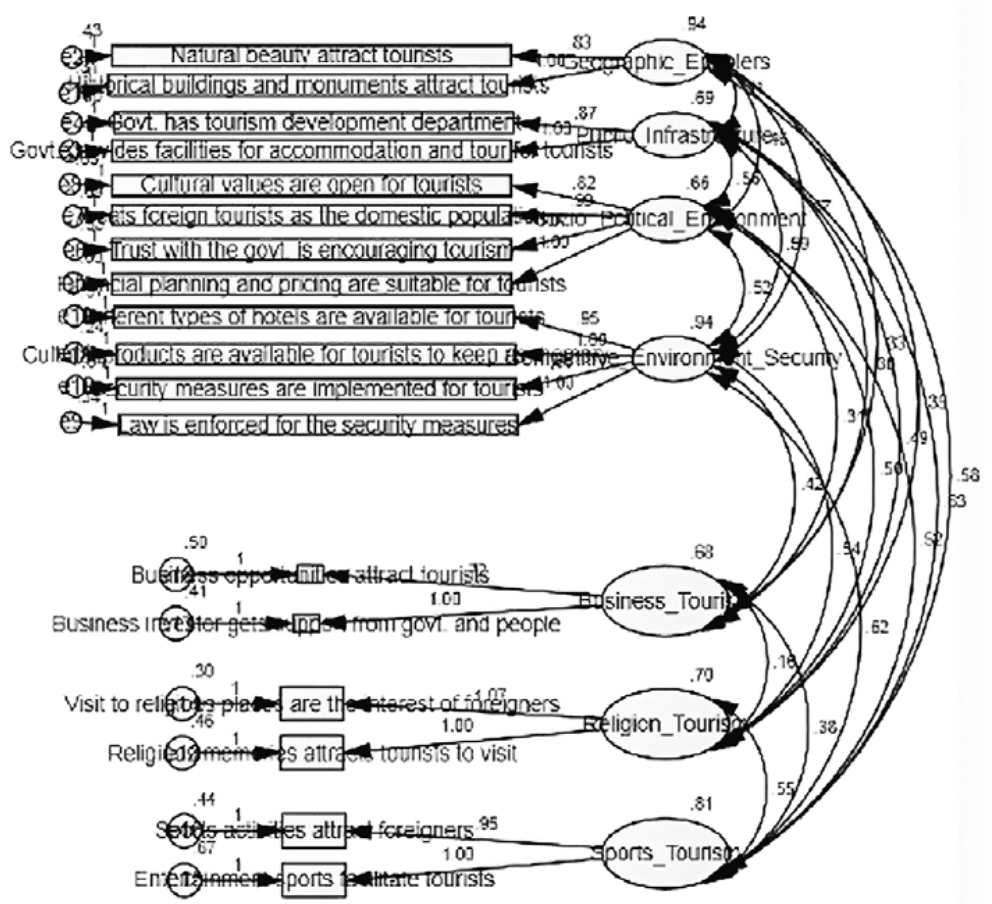

Figure 3. AMOS Model Outcome

\section{Conclusion}

The study concludes that the tourism sector development is completely based on tourism enablers. The first objective could get reached through this study that there are possibilities for business, religion and sports tourism though the challenge for establishing the health and education tourism. So government should get active for the support and promotion of tourism enablers. The second objective reached as well knowing there are four types of enablers (geographic, public infrastructure, socio political environment and competitive environment \& security) is efficient for the three types of tourism. As well development will be with the tourism enablers, the more opportunities will arise for the tourism sector. The last objective also gets achieved using the statistical test regression analysis having the $\mathrm{R}^{2} 0.615$ and Beta 0.786 shows a strong relationship and effect lies with tourism enablers on tourism sector. Based on the current scenario, there might be many limitations but for the future the geographic enablers, public infrastructure, socio political environment and competitive environment and security must get special care and dedication. The outcome of the AMOS model also supports the concept and strengthens the idea to promote the tourism sector by supporting the tourism enablers. In the future the health and education tourism can also get established, condition to developing all dimensions of tourism enablers. 


\section{Reference}

Ahmad, N. I. 2014. Cultural Heritage Tourism in Malaysia: Issues and Challenges. Universiti Sains Malaysia.

Allen, J., O’Toole, W., McDonnell, I., Harris, R. 2002. Festival and special event management (2nd ed.). Australia, Milton: Wiley.

Anwar, S., Sohail, S. 2004. Festival tourism in the United Arab Emirates: First-time visitors versus repeat visitor perceptions. Journal of Vacation Marketing 10(2), 161-170.

Ayob, N. M. 2014. The problems of managing tourism business. ASA University Bangladesh.

Barker, M., Page, S., Meyer, D. 2003. Urban visitor perceptions of safety during a special event. Journal of Travel Research 41, 355-361.

Brannas, K., Nordstrom, J. 2006. Tourist accommodation effects of festivals. Tourism Economics 12(2), 291-302.

Chalip, L., Costa, C. 2006. Building sport event tourism into the destination brand: Foundations for a general theory. In H. Gibson (Ed.), Sport tourism: Concepts and theories, 86-105. London: Routledge.

Cohen J. 1992. Quantitative Methods in Psychology. Psychological Bulletin 1, 155-159.

Donovan, A., Debres, K. 2006. Foods of freedom: Juneteenth as a culinary tourist attraction. Tourism Review International 9(4), 379-389.

Dwyer, L., Forsyth, P., Spurr, R. 2005. Estimating the impacts of special events on an economy. Journal of Travel Research 43(4), 351-359.

EKurd. (2015, June 15). Iraqi Kurdistan tourism sector is undergoing its worst stages. Retrieved January 09, 2016, from http://ekurd.net/iraqi-kurdistan-tourism-sector-is-undergoing-its-worst-stages-2015-06-15

Gammon, S., Kurtzman, J. 2002. Sport tourism: Principles and practice. Eastbourne: Leisure Studies Association Publications.

Hannam, K., Halewood, C. 2006. European Viking themed festivals: An expression of identity. Journal of Heritage Tourism 1(1), 17-31.

Hinch, T., Jackson, E., Hudson, S., Walker, G. 2006. Leisure constraint theory and sport tourism. In H. Gibson (Ed.), Sport tourism: Concepts and theories, 10-31. London: Routledge.

Jago, L., Dwyer, L. 2006. Economic evaluation of special events: A practitioner's guide. Gold Coast Australia: Cooperative Research Centre for Sustainable Tourism.

Lim, S., Lee, J. 2006. Host population perceptions of the impact of mega-events. Asia Pacific Journal of Tourism Research 11(4), 407-421.

Mehmetoglu, M., Ellingsen, K. 2005. Do small-scale festivals adopt "market orientation" as a management philosophy? Event Management 9(3), 119-132.

Oliveria, E. (2014). The tourism potential of Northern Portugal. Akdeniz Univeristy Tourism Faculty.

Ray, N., McCain, G., Davis, D., Melin, T. 2006. Lewis and Clark and the Corps of Discovery: Re-enactment event tourism as authentic heritage travel. Leisure Studies 25(4), 437-454.

Severt, D., Wang, Y., Chen, P., Breiter, D. 2007. Examining the motivation, perceived performance, and behavioural intentions of convention attendees: Evidence from a regional conference. Tourism Management 28(2), 399-408.

Sherwood, P. 2007. A triple bottom line evaluation of the impact of special events: the development of indicators. Unpublished Doctoral dissertation, Victoria University, Melbourne.

Thett, K. K. 2012. Responsible Tourism in Myanmar:Current Situation and Challenges. A resident of Nyaung Bin Gyi Village in Monywa. 
Tourism Board. 2015. Erbil | Unbelieveable Kurdistan. Retrieved January 9, 2016, from http:// bot.gov.krd/erbil-province/erbil

Tuli, F. A. 2014. The Problems of Managing Tourism Business. Global disclosure of Economics and Business.

Tum, J., Norton, P., Wright, J. 2006. Management of event operations. Oxford: Butterworth-Heinemann/Elsevier.

Van der Wagen, L. 2006. Human resource management for events: Managing the event workforce. Oxford: Butterworth-Heinemann.

Waitt, G. 2004. A critical examination of Sydney's 2000 Olympic games, In I. Yeoman, et al. (Eds.), Festivals and events management, 391-408. Oxford: Elsevier.

Weber, K., Ladkin, A. 2004. Trends affecting the convention industry in the 21st century. Journal of Convention and Event Tourism 6(4), 47-63.

Weed, M. 2005. Sports tourism theory and method: Concepts, issues and epistemologies. European Sport Management Quarterly 5(3), 229-242.

Xiao, H., Smith, S. 2004. Residents' perceptions of Kitchener- Waterloo Oktoberfest: An inductive analysis. Event Management 8(3), 161-175.

Yoo, J., Weber, K. 2005. Progress in convention tourism research. Journal of Hospitality and Tourism Research 29(2), 194-222.

Yahoo News. 2015, February 1. Iraqi Kurdistan tourism in tatters as IS war drags on. Retrieved January 9, 2016, from http://news.yahoo.com/iraqi-kurdistan-tourism-tatters-war-drags-094555480.html

Yoon, S., Spencer, D., Holecek, D., Kim, D. 200o. A profile of Michigan's festival and special event tourism market. Event Management 6(1), 33-44. 


\section{Appendix}

\begin{tabular}{|c|c|c|c|c|c|c|}
\hline \multicolumn{7}{|c|}{$\begin{array}{l}\text { This survey instrument is gettin } \\
\text { collected through this will get } \\
\text { valued contribution. Please cho } \\
\text { Demographical Information }\end{array}$} \\
\hline \multicolumn{7}{|c|}{ Gender: (1) Male (2) Female } \\
\hline \multicolumn{3}{|c|}{ Age: $\begin{array}{ll}\text { (A) } 16 \text { years }-25 \text { years } & \text { (B) } 26 \text { years }-35 \text { years }\end{array}$} & \multicolumn{4}{|c|}{$\begin{array}{ll}\text { (D) } 46 \text { years }-55 \text { years } & \text { (E) } 56 \text { years and more }\end{array}$} \\
\hline \multicolumn{7}{|c|}{ Marital Status: $\quad$ (A) Single $\quad$ (B) Married } \\
\hline \multicolumn{7}{|c|}{ Education: $\quad(A)$ Secondary $\quad$ (B) Intermediate $\quad$ (C) Graduate $\quad$ (D) Post Graduate $\quad(E)$ Ph.D. } \\
\hline \multicolumn{5}{|c|}{ Family Income/ Month: $\quad$ (A) Up to $\$ 1000 \quad$ (B) $\$ 1001-\$ 2000$} & $($ E) $\$ 40$ & nd more \\
\hline \multicolumn{7}{|c|}{ 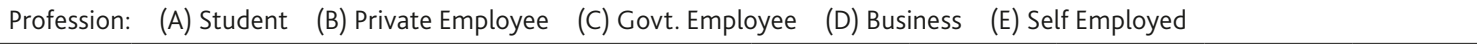 } \\
\hline \multicolumn{7}{|c|}{ Measuring the effect of Enablers of Tourism as Opportunity on Tourism Sector } \\
\hline Sl. No. & Items & $\begin{array}{c}\text { Strongly } \\
\text { Disagree } \\
\text { (1) }\end{array}$ & $\begin{array}{c}\text { Disagree } \\
\text { (2) }\end{array}$ & $\begin{array}{c}\text { Neutral } \\
\text { (3) }\end{array}$ & $\begin{array}{c}\text { Agree } \\
(4)\end{array}$ & $\begin{array}{c}\text { Strongly } \\
\text { Agree } \\
\text { (5) }\end{array}$ \\
\hline 1 & Natural beauty attract tourists & & & & & \\
\hline 2 & Historical buildings and monuments attract tourists & & & & & \\
\hline 3 & Govt. has tourism development department & & & & & \\
\hline 4 & $\begin{array}{l}\text { Govt. provides facilities for accommodation and } \\
\text { tour for tourists }\end{array}$ & & & & & \\
\hline 5 & Cultural values are open for tourists & & & & & \\
\hline 6 & Treats foreign tourists as the domestic population & & & & & \\
\hline 7 & Trust with the govt. is encouraging tourism & & & & & \\
\hline 8 & $\begin{array}{l}\text { Financial planning and pricing are suitable for } \\
\text { tourists }\end{array}$ & & & & & \\
\hline 9 & Different types of hotels are available for tourists & & & & & \\
\hline 10 & $\begin{array}{l}\text { Cultural products are available for tourists to keep } \\
\text { as memory }\end{array}$ & & & & & \\
\hline 11 & Security measures are implemented for tourists & & & & & \\
\hline 12 & Law is enforced for the security measures & & & & & \\
\hline 13 & Healthcare specialty attract tourists & & & & & \\
\hline 14 & $\begin{array}{l}\text { Medical treatment is better and cheaper than } \\
\text { neighboring countries }\end{array}$ & & & & & \\
\hline 15 & Business opportunities attract tourists & & & & & \\
\hline 16 & $\begin{array}{l}\text { Business investor gets support from govt. and } \\
\text { people }\end{array}$ & & & & & \\
\hline 17 & $\begin{array}{l}\text { Educational institutions are the interest for foreign } \\
\text { students }\end{array}$ & & & & & \\
\hline 18 & $\begin{array}{l}\text { Ministry of Higher Education promotes the } \\
\text { education facility for foreigners }\end{array}$ & & & & & \\
\hline 19 & Visit to religious places are the interest of foreigners & & & & & \\
\hline 20 & Religious memories attracts tourists to visit & & & & & \\
\hline 21 & Sports activities attract foreigners & & & & & \\
\hline 22 & Entertainment sports facilitate tourists & & & & & \\
\hline
\end{tabular}

